\title{
Effect of photobiomodulation on the viability of osteoblasts and fibroblasts submitted to alendronate sodium or zoledronic acid: an in vitro study
}

\author{
- Mariana Aparecida Brozoski Oral and Maxillofacial Surgery Department, School of Dentistry, Universidade de São Paulo, São \\ Paulo, SP, Brazil • Natalia Caroline Aguiar Tartaroti Oral and Maxillofacial Surgery Department, School of Dentistry, Universidade \\ de São Paulo, São Paulo, SP, Brazil • Andreia Aparecida Traina Oral and Maxillofacial Surgery Department, School of Dentistry, \\ Universidade de São Paulo, São Paulo, SP, Brazil • Maria Cristina Zindel Deboni Oral and Maxillofacial Surgery Department, \\ School of Dentistry, Universidade de São Paulo, São Paulo, SP, Brazil • Marcia Martins Marques Department of Restorative \\ Dentistry, School of Dentistry, Universidade de São Paulo, São Paulo, SP, Brazil • Maria da Graça Naclério Homem Oral and \\ Maxillofacial Surgery Department, School of Dentistry, Universidade de São Paulo, São Paulo, SP Brazil
}

ABSTRACT | The goal of this study is to evaluate the effect of photobiomodulation therapy (PBMT) on the viability of osteoblasts and cultured fibroblasts in different concentrations of alendronate or zoledronic acid. Two cell lines: osteoblast-like mouse cells (OSTEO 1) and human buccal mucosa fibroblast (FMM1) were used. Cells were submitted to different concentrations of bisphosphonates $(1 \mu \mathrm{M}, 10 \mu \mathrm{M}$, and $100 \mu \mathrm{M}$ sodium alendronate and $3 \mu \mathrm{M}, 5 \mu \mathrm{M}$ and $10 \mu \mathrm{M}$ zoledronic acid) for 24 hours. Next, the cultures received PBMT. The irradiations were applied with a diode laser (InGaAIP, $660 \mathrm{~nm}, 30 \mathrm{~mW}$, spot $0.028 \mathrm{~cm} 2)$ in continuous, punctual and contact mode at two energy densities: $5 \mathrm{~J} / \mathrm{cm} 2$ (4.5 s) or $10 \mathrm{Jcm} 2$ (9s) with 6 hours-intervals. Cell viability was determined by mitochondrial activity assay (MTT) $24 \mathrm{~h}$ after the last irradiation. The data were compared by the one way- ANOVA, complemented by the Tukey's test $(\mathrm{p}<0.05)$. Sodium alendronate at concentrations of $100 \mu \mathrm{M}$ and $10 \mu \mathrm{M}$ and zoledronic acid at $10 \mu \mathrm{M}$ concentration showed higher long-term toxicity. The cellular viability of the PBMT treated group was significantly higher than that of the negative control group. The same occurred with the osteoblasts treated with the highest concentrations of the drug $(5$ and $10 \mu \mathrm{M})$, despite not reaching the cell viability of the positive control group, it presented greater viability than the negative control where the cells were not irradiated. In the groups submitted to zoledronic acid, positive controls presented greater cell viability. We concluded that under the parameters applied in this study, PBMT at an energy density of $5 \mathrm{~J} / \mathrm{cm} 2$ was able to revert the toxicity of sodium alendronate applied at the higher concentrations in both cell types, whereas zoledronic acid toxicity, regardless of its concentrations, was not influenced by PBMT.

DESCRIPTORS | Osteonecrosis of the Jaws; Laser; Alendronate; Zoledronic Acid.

RESUMO | 0 efeito da fotobiomodulação na viabilidade de osteoblastos e fibroblastos submetidos ao alendronato de sódio ou ácido zoledrônico: um estudo in vitro • O objetivo deste estudo é avaliar o efeito da terapia de fotobiomodulação (TFBM) na viabilidade de osteoblastos e cultura de fibroblastos em diferentes concentrações de alendronato ou ácido zoledrônico. Duas linhagens celulares - células de camundongos semelhantes a osteoblastos (OSTEO 1) e fibroblastos de mucosa bucal humana (FMM1) - foram utilizadas. As células foram submetidas a diferentes concentrações de bisfosfonatos $(1 \mu \mathrm{M}, 10 \mu \mathrm{M}$ e $100 \mu \mathrm{M}$ de alendronato de sódio e $3 \mu \mathrm{M}, 5 \mu \mathrm{M}$ e $10 \mu \mathrm{M}$ de ácido zoledrônico) por 24 horas. Em seguida, as culturas receberam TFBM. As irradiações foram aplicadas com laser de diodo (InGaAIP, 660 nm, $30 \mathrm{~mW}$, spot 0,028 cm2) em modo contínuo, pontual e de contato, em duas densidades de energia: $5 \mathrm{~J} / \mathrm{cm} 2(4,5 \mathrm{~s})$ ou $10 \mathrm{~J} / \mathrm{cm} 2$ (9s) com intervalos de 6 horas. A viabilidade celular foi determinada pelo ensaio de atividade mitocondrial (MTT) $24 \mathrm{~h}$ após a última irradiação. Os dados foram comparados pelo ANOVA One-Way, complementado pelo teste de Tukey $(\mathrm{p}<0,05)$. O alendronato de sódio nas concentrações de $100 \mu \mathrm{M}$ e $10 \mu \mathrm{M}$ e o ácido zoledrônico na concentração de $10 \mu \mathrm{M}$ apresentaram maior toxicidade a longo prazo. A viabilidade celular do grupo tratado com TFBM foi significativamente maior que a do grupo de controle negativo. O mesmo ocorreu com os osteoblastos tratados com as maiores concentrações do fármaco (5 e $10 \mu \mathrm{M})$, apesar de não atingir a viabilidade celular do grupo de controle positivo, apresentou maior viabilidade do que o controle negativo no qual as células não foram irradiadas. Nos grupos submetidos ao ácido zoledrônico, controles positivos apresentaram maior viabilidade celular. Concluímos que sob os parâmetros aplicados neste estudo, a TFBM, com uma densidade de energia de $5 \mathrm{~J} / \mathrm{cm} 2$, foi capaz de reverter a toxicidade do alendronato sódico aplicado nas concentrações mais altas em ambos os tipos celulares, enquanto a toxicidade do ácido zoledrônico, independentemente de suas concentrações, foi não influenciada pela TFBM.

DESCRITORES Osteonecrose dos Maxilares; Laser; Alendronato; Ácido Zoledrônico.

CORRESPONDING AUTHOR ～• Maria da Graça Naclério Homem Oral and Maxillofacial Surgery Department, School of Dentistry, Universidade de São Paulo, São Paulo, SP Brazil • Av. Prof. Lineu Prestes, 2227 São Paulo, SP, Brazil • 05508-000 E-mail: mgracanh@usp.br

- Received Nov 14, 2018 • Accepted Dec 10, 2018

- Dol http://dx.doi.org/10.11606/issn.2357-8041.clrd.2019.151831 


\section{INTRODUCTION}

Bisphosphonates (BFs) are drugs used since 1960 for the treatment of diseases of bone metabolism, such as bone metastases of lung, prostate and breast cancers; multiple myeloma; Paget's disease; among others. ${ }^{1,2}$ Nowadays therapeutic use, of that drugs, has increased primarily for the treatment and prevention of osteoporosis and osteopenia. ${ }^{3}$ Despite their therapeutic efficacy, these treatments with BFs may cause undesirable side effects. Among them, osteonecrosis of the jaws. This condition was initially known as Bisphosphonate-related osteonecrosis of the jaw (BRONJ).

Over time it was observed that BRONJ side effect, also occurred in patients submitted to other drugs used in the control of bone metabolism (new antiresorptive and antiangiogenic drugs), that is, this osteonecrosis was not exclusively the result of the use of bisphosphonates. For this reason, in 2014, the term BRONJ was replaced by a wider one, namely Medication-related osteonecrosis of the jaw (MRONJ). ${ }^{2}$

MRONJ is an oral lesion that is difficult to resolve, it imposes treatments with the use of antibiotics for prolonged periods, surgical debridement, and even resections that lead the patient to functional and aesthetic loss with a significant decrease in quality of life. The pathophysiology of MRONJ has not yet been fully elucidated. It is well known that bisphosphonates and other anti-resorptive medications have two fundamental biological effects, namely: inhibition of calcification when administered in high doses, and inhibition of bone resorption related to anti-osteoclast and antiangiogenic activity. ${ }^{4-6}$

The diagnosis of MRONJ is based on the patient's history and clinical examination. It is presented as a necrotic bone exposure, ranging from a few millimeters to larger areas, which may remain asymptomatic for weeks, months, or years. In $60 \%$ of cases, pain may be present when inflammation or infection of adjacent tissues occurs.?

Several types of treatment have been proposed for MRONJ, including surgical debridement, antibiotic therapy, ${ }^{2,3}$ ozonotherapy ${ }^{7,8}$ and photobiomodulation therapy (PBMT).9-11 In vivo and in vitro studies demonstrated success when PBMT was applied in different parameters. ${ }^{12}$ However, the underlying mechanisms involved in PBMT effects in the treatment of MRONJ have not yet been fully elucidated.

In the search for these mechanisms, and knowing that the repair of MRONJ lesions involves cells such as osteoblasts and fibroblasts, this study aimed to evaluate in vitro the effect of PBMT, when applied with different parameters, checking the viability of these cells under the influence of different concentrations of two BFs: alendronate sodium and zoledronic acid.

\section{METHODS}

This study was approved by the Research Ethics Committee of the School of Dentistry of the University of São Paulo (FOUSP) (Seem \#280.024). Two cell lines were used: line OSTEO 1 composed of osteoblasts-like cells originating from parietal bone periosteum of newborn mouses, ${ }^{13,14}$ and line FMM1 composed of human buccal mucosal fibroblast cells ${ }^{15}$ kindly donated by the Basic Research Laboratory of the Department of Dentistry of FOUSP.

\section{Cell culture}

Cells were defrosted and cultivated in DMEM with $10 \%$ fetal bovine serum and $1 \%$ antibioticantimycotic solution (Sigma Chemical, St. Louis, MO, USA) in $75 \mathrm{~mm} 3$ culture flasks. Daily monitoring of cell's growth was performed using inverted phase microscopy and the culture medium was changed every 2 days, according to the cellular metabolism. When they reached 70\% confluency in the flask they 
were trypsinized and subculture into 448 well plates (50o cells per well) for each experimental group.

\section{Substances}

Sodium Alendronate and Zoledronic Acid were used. Sodium Alendronate 99\% (Formula e Ação, São Paulo, SP, Brazil), has molecular weight of $325.12 \mathrm{~g} /$ mol and chemical formula $\mathrm{C}_{4} \mathrm{H}_{12} \mathrm{NNaO}_{7} \mathrm{P}_{2} .3 \mathrm{H}_{2} \mathrm{O}$. Zoledronic Acid (Zometa ${ }^{\circledR}$ - Novartis Pharma Stein AG, Stein, Switzerland) has a molecular weight of $272.08 \mathrm{~g} / \mathrm{mol}$ and chemical formula $\mathrm{C}_{5} \mathrm{H}_{8} \mathrm{~N}_{2} \mathrm{Na}_{2} \mathrm{O}_{7} \mathrm{P} 2 \cdot 4 \mathrm{H}_{2} \mathrm{O}$.

\section{Photobiomodulation therapy (PBMT)}

PBMT was applied with a low power continuous diode laser (Photon Lase, DMC Equipamentos LTDA, São Carlos, SP, Brazil). The irradiations were performed in the following parameters: wavelength: $660 \mathrm{~nm}$ (active medium InGaAlP); beam area: $0.028 \mathrm{~cm} 2$; power: $30 \mathrm{~mW}$; power density: $0.714 \mathrm{~W} /$ cm2; energy densities: $5 \mathrm{~J} / \mathrm{cm} 2$ or $10 \mathrm{~J} / \mathrm{cm} 2$; time of irradiation per point: $4.5 \mathrm{~s}$ or $9 \mathrm{~s}$, respectively; energy per point: $0.08 \mathrm{~J}$ or $0.14 \mathrm{~J}$, respectively. Irradiation was performed in point mode, in contact at a single point in the center of each well of the culture plates. Two irradiations were performed with a 6-hour interval. The plates that did not undergo irradiation (controls) received the same experimental treatments of the irradiated plates simulating each step of the PBMT, but with the equipment turned off.

\section{Experimental Groups}

Control: Cells (Osteo-1 or FMM1) grown in conventional medium (DMEM with 10\% fetal bovine serum and $1 \%$ antibiotic-antimycotic solution (Sigma Chemical).

Bisphosphonate: Cells (Osteo-1 or FMM1) grown in conventional conditioned medium with Alendronate Sodium $(1 \mu \mathrm{M}, 10 \mu \mathrm{M}$ or $100 \mu \mathrm{M})$ or Zoledronic Acid (3 $\mu \mathrm{M}, 5 \mu \mathrm{M}$ or $10 \mu \mathrm{M})$.
PBMT 5J / cm2: Cells (Osteo-1 or FMM1) grown in medium containing different concentrations of Alendronate Sodium $(1 \mu \mathrm{M}, 10 \mu \mathrm{M}$ or $100 \mu \mathrm{M})$ or Zoledronic Acid ( $3 \mu \mathrm{M}, 5 \mu \mathrm{M}$ or $10 \mu \mathrm{M})$ and irradiated with energy density of $5 \mathrm{~J} / \mathrm{cm} 2$.

PBMT 10 J/cm2: Cells (Osteo-1 or FMM1) grown in medium containing different concentrations of Alendronate Sodium $(1 \mu \mathrm{M}, 10 \mu \mathrm{M}$ or $100 \mu \mathrm{M})$ or Zoledronic Acid $3 \mu \mathrm{M}, 5 \mu \mathrm{M}$ or $10 \mu \mathrm{M}$ ) and irradiated with energy density of $10 \mathrm{~J} / \mathrm{cm} 2$.

\section{Cell viability}

Cell viability analysis was based on the MTT reduction assay (MTT 3- (4,5-dimethylthiazol-2yl) -2,5-diphenyltetrazolium bromide). Twenty-four hours after plating, the cells, according to the experimental groups, received the conditioned media or not (control). Immediately afterward they were submitted to PBMT or not. Then, 24 hours after the last irradiation the cultures were submitted to the MTT reduction test. ${ }^{15}$ This test measures the ability of mitochondrial enzymes produced by metabolically active cells to reduce MTT (Invitrogen, Eugene, OR, USA) to an insoluble formazan salt, which after being dissolved in DMSO (Dimethyl sulfoxide) which was then measured by absorbance at $562 \mathrm{~nm}$ in a spectrophotometer (Amersham Biosciences, Biochrom Ltd., Cambridge, England).

\section{Statistical analysis}

The results of the cell viability tests obtained in optical density were transformed into percentage of cell viability. The mean of the results from the control group was considered as $100 \%$ viability. The percentages of cell viability of the different experimental groups were compared by the ANOVA - 1 criteria, complemented by the Tukey's test. The statistical program BioEstat version 5.0 $(\mathrm{p}<0.05)$ was used. 


\section{RESULTS}

The percentages of cell viability of both cell lines (Osteo1 and FMM1) of the different experimental groups are graphically illustrated in Figure 1 namely: PC-positive control- cultured under ideal conditions; NC negative control-treated with sodium alendronate and no further treatment and those who underwent alendronate sodium and PBMT at two power densities ( 5 and $10 \mathrm{~J} / \mathrm{cm} 2$ ) within twenty-four hours after the last irradiation.

The viability of the positive control group of Osteo 1 cells, considered to be $100 \%$ viability, was significantly higher than that of all the other groups in the different concentrations of sodium alendronate. At the lowest concentration, the viability percentages of all experimental groups were similar. At higher concentrations (e.g., $10 \mu \mathrm{m}$ and $100 \mu \mathrm{m}$ ) the PBMT-treated group in the $5 \mathrm{~J} /$ cm2 parameter showed significantly greater cell viability than the negative control group within the same concentration of alendronate sodium. The cell viability of the $10 \mathrm{~J} / \mathrm{cm} 2$ treated group was intermediate, like the negative control and the $5 \mathrm{~J} /$ cm2 group, also within the same concentrations.

The viability of the FMM1 cell control group, which was $100 \%$ viability, was like the cellular viability of the $5 \mathrm{~J} / \mathrm{cm} 2$ group previously submitted to all alendronate sodium concentrations and to the $10 \mathrm{~J} / \mathrm{cm} 2$ group only in the concentration lower (1æM). At the highest concentration of sodium alendronate $(100 \mu \mathrm{m})$, the group treated with $5 \mathrm{~J} /$ cm2 presented significantly greater viability than the negative control group and the group treated with $10 \mathrm{~J} / \mathrm{cm} 2$ ( $<$ 0.05). In the other concentrations, the viability of all the experimental groups was similar (Figure 1).

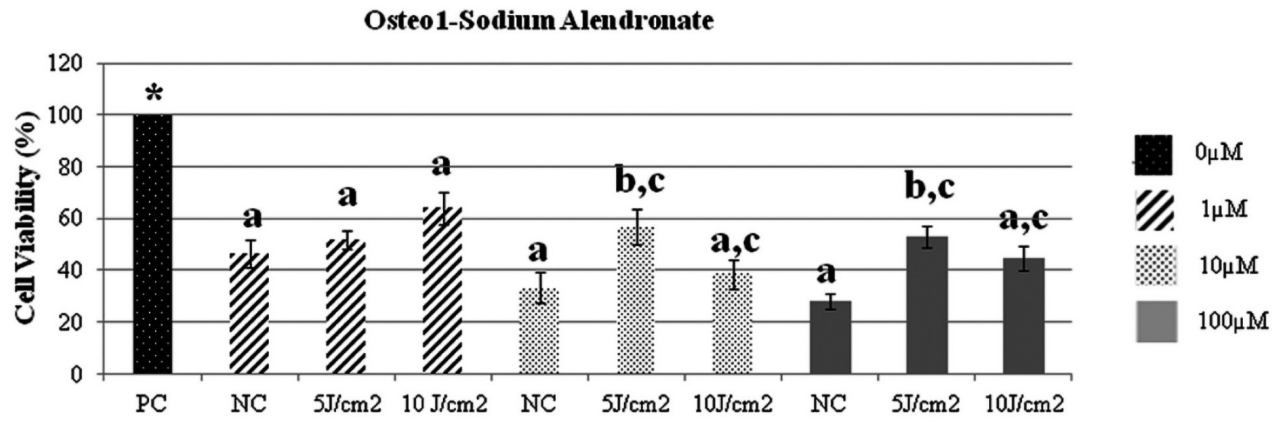

FMM1-Sodium Alendronate

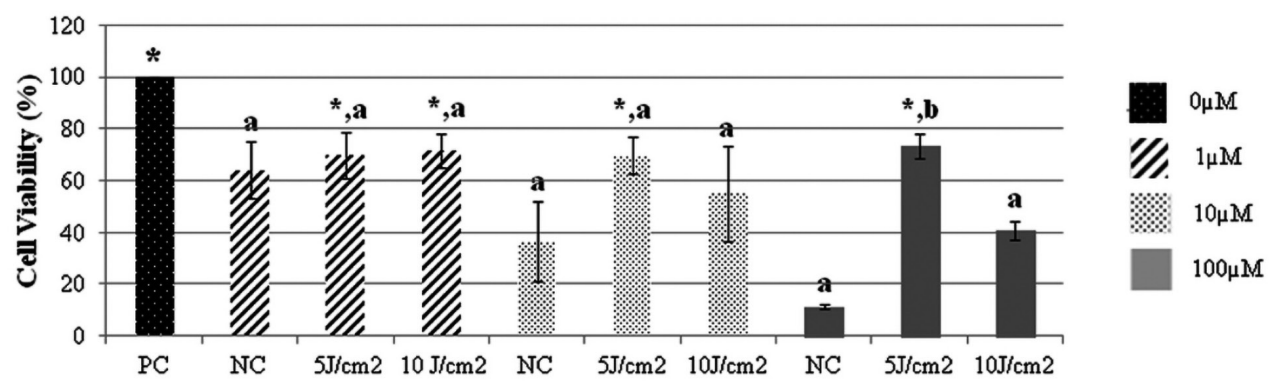

Figure 1 | Graphical representation of the cell viability of osteoblasts OSTEO1 lineage - and FMM1 fibroblasts submitted to alendronate sodium at concentrations $0 \mu \mathrm{m}$ (Positive Control), $1 \mu \mathrm{m}, 10 \mu \mathrm{m}$ and $100 \mu \mathrm{m}$ in the different experimental groups [Control-treatment and those treated by PBMT in the two densities of power ( 5 and $10 \mathrm{~J} / \mathrm{cm} 2)$ ]. Different letters indicate significant differences between the experimental groups in the same concentration of sodium alendronate $(p<0.01)$ * Similar to the positive control. 
The viability of the positive control group of both cell types (Osteo1 and FMM1), considered to be $100 \%$ viability, was significantly higher than that of all the other groups in the different concentrations of zoledronic acid $(\mathrm{p}<0.01)$. There were no differences between the viabilities of the other groups in all concentrations of zoledronic acid tested (Figure 2).
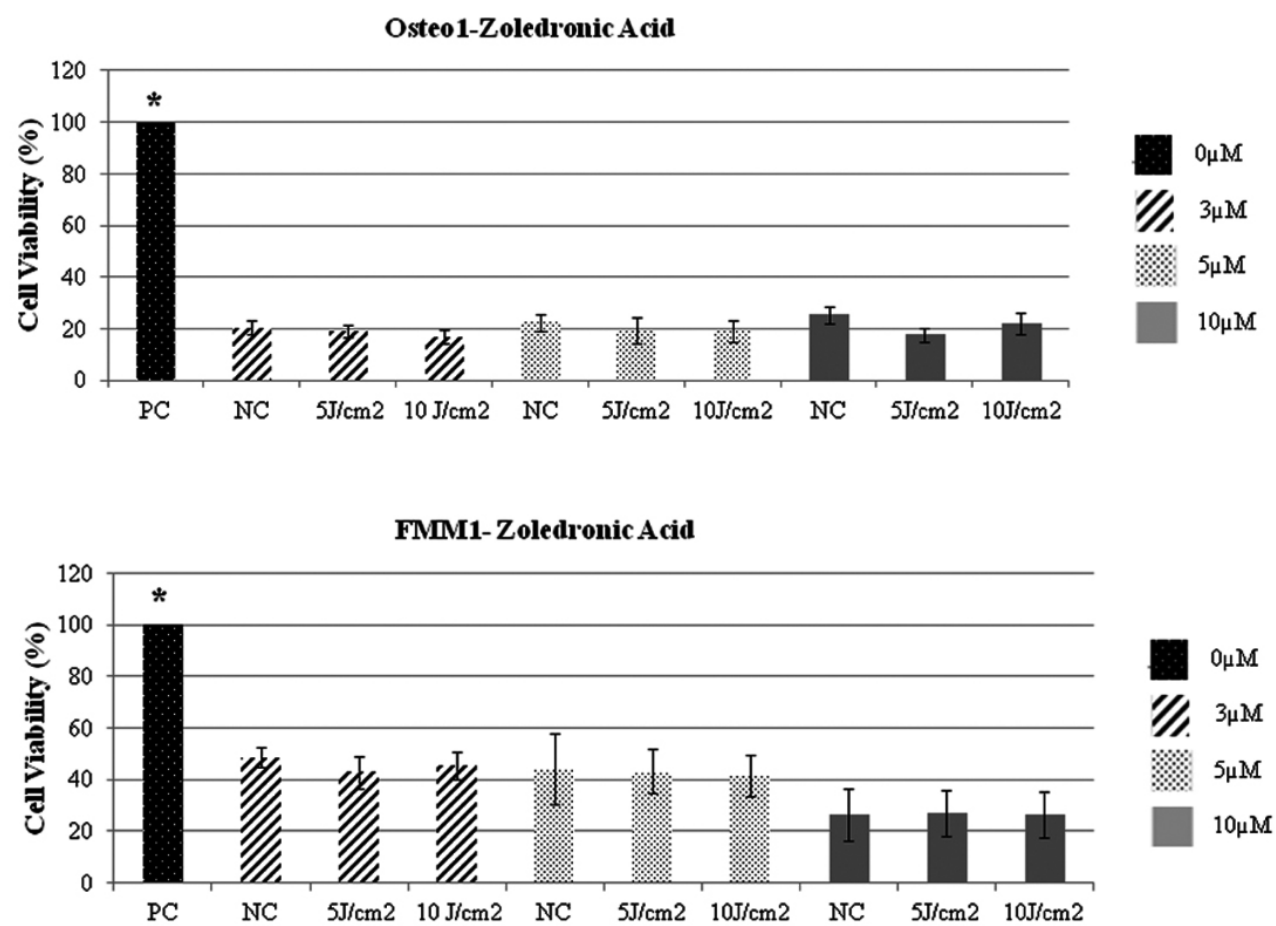

Figure 2 | Graphical illustrates the cell viability percentages of both cell types (Osteo1 and FMM1) of the different experimental groups, namely: PC-positive control- cultured under optimal conditions; NC negative control-treated with zoledronic acid and no further treatment and those who underwent zoledronic acid and PBMT at two power densities (5 and $10 \mathrm{~J} / \mathrm{cm} 2)$ within twenty-four hours after the last irradiation.

\section{DISCUSSION}

Drug-related maxillary osteonecrosis is strongly implicated using bisphosphonates, especially sodium alendronate and zoledronic acid. ${ }^{16,17}$ PBMT applied in different parameters has shown beneficial effects in the treatment of these lesions, but little is known about the mechanisms involved in this effect. It is believed that the effect is more related to increased local circulation and VEGF secretion. However, PBMT has also been identified as a therapy that prevents cell death. ${ }^{18}$ With these data, the present study aimed to verify a possible beneficial effect of photobiomodulation therapy on the maintenance of the viability of fibroblasts and osteoblasts, cells involved in the regeneration of tissues affected by MRONJ lesions. The viability of these cells submitted to different concentrations of sodium alendronate or zoledronic acid was evaluated. It was found that zoledronic acid at the different concentrations tested was highly toxic and that PBMT was not able to reverse this effect. PBMT exerted a beneficial effect on the fibroblasts submitted to the parameter of lower energy density ( $5 \mathrm{~J} / \mathrm{cm} 2)$, which was able to maintain cellular viability levels like that of the positive control group cultured under the best conditions.

Since the first publication in 2003 reporting bisphosphonate-induced osteonecrosis ${ }^{16}$ the subject has gained repercussion in the scientific community, 
but countless questions remain unanswered. The exact mechanism of how this class of medication works in the development of osteonecrosis is not yet established. It is known that the type of medication, the time of use and the route of administration are factors that influence MRONJ. ${ }^{1-7}$ Some authors cite that the cytotoxicity of the drug is one of the factors for the development of osteonecrosis. ${ }^{5,6}$ Others point out that the local microbiota is a determining factor for lesion appearance. ${ }^{16,17,19}$ The association between altered bone metabolism, cytotoxicity, decreased angiogenesis, microbiota and the constant microtrauma affecting the oral cavity are the most cited factors in the pathophysiology of MRONJ. ${ }^{4}$

There is no consensus in the literature regarding treatment protocols for MRONJ. Several types of conducts are employed, from clinical follow-up and antibiotic therapy to large resections of the maxilla and mandible..$^{3,17,9}$ The PBMT applied both to the wavelength in the red and infrared spectrum has been applied with positive results in cases of MRONJ.9-11

The use of Nd: YAG laser for the treatment of MRONJ for PBMT, associated or not to the surgical procedure, presented good clinical results. ${ }^{11} \mathrm{MRONJ}$ lesions treated by the combination of PBMT with drug treatment and surgery have a higher rate of injury repair than when lesions are treated solely by medications and surgery probably by increased angiogenesis. ${ }^{9}$

Previous studies have already shown that PBMT is able to compensate for the cytotoxic effect of substances applied on cells of oral tissues, such as human buccal mucosa fibroblasts submitted to dental bleaching gels, ${ }^{20}$ as well as stem cells from human dental pulps submitted to dental adhesives. ${ }^{21}$ Moreover, in translational studies in rats, we observed that PBMT was able to prevent cell death. ${ }^{18}$ Based on these results we hypothesized that the beneficial effects of PBMT in the treatment of MRONJ lesions perhaps might be related to the control of the cytotoxic effect of ant reabsorbing drugs on the cells of the oral tissues such as fibroblasts and osteoblasts. For this reason, we submitted these cell types to different concentrations of two of the most BFs related to the development of MRONJ, sodium alendronate and zoledronic acid and applied PBMT to verify whether this therapy could positively influence the ability of these cells to survive the toxic effects of BFs.

The cytotoxicity of bisphosphonates has been demonstrated by different in vitro studies, where the concentration of the medication, the type of the cell, and the time of contact with the drug influence the toxic effect on the cells. ${ }^{22-24}$ In this study, we used high drug concentrations (Alendronate sodium $-100 \mu \mathrm{m}$, $10 \mu \mathrm{m}-$ and zoledronic acid, $5 \mu \mathrm{m}$, and $10 \mu \mathrm{m}$ ) to submitted cells to the highest toxicity challenge.

Clinical studies use laser light with diverse parameters, using wavelengths in the spectrum from red to infrared was successfully for the treatment of MRONJ.9,25,26 It is known that the parameters used for PBMT influence the results obtained. ${ }^{27}$ In the present work, the parameters applied were those determined in previous studies that observed that lower energy density was more effective to stimulate cells in culture. ${ }^{27-30}$

The results of the present study demonstrated that zoledronic acid even at the highest concentration used (10 $\mu \mathrm{M}$ ) showed higher long-term toxicity, as did sodium alendronate at concentrations of $100 \mu \mathrm{M}$ and $10 \mu \mathrm{M}$. Sodium alendronate at $1 \mu \mathrm{M}$ concentration was not cytotoxic for the cells used, and therefore PBMT did not alter the cell viability of the cells of this experimental group since the cells had metabolic alteration neither by nutritional deficit nor by the cytotoxicity of the drug to which were exposed. In fact, Almeida Lopes et al. in $2001^{30}$ have already observed that nutritional deficiency in cultured cells was critical for cells to respond to PBMT.

We observed that in the parameters and concentrations used PBMT was able to partially reverse the cytotoxicity of alendronate, but not 
zoledronic acid. On the other hand, PBMT has been shown to modulate cellular metabolism. Some in vitro studies have demonstrated that PBMT can accelerate the growth of fibroblasts, osteoblasts and endothelial cells. ${ }^{27-33}$ It is known that PBMT presents numerous benefits such as modulation of the inflammatory process, acceleration of tissue repair, and favors angiogenesis and promotes analgesia. ${ }^{31}$ Endothelial cells exhibited their increased proliferation when subjected to $\mathrm{PBMT}^{23}$ induces secretion of growth factors, such as fibroblast growth factor (FGF) $3^{32}$ PBMT also positively affects the proliferation and differentiation of human stem cells. ${ }^{33-35}$ These factors are important for PBMT to be considered promising for the treatment of MRONJ.

\section{CONCLUSIONS}

This study has shown that PBMT could be a relevant adjunctive therapy for improving healing after surgeries done in patients under alendronate therapy.

Finally, new PBMT protocols could tested in future in order to find effective parameters to be applied in patients under BFs treatment or to treat MRONJ lesions.

\section{ACKNOWLEDGMENTS}

The authors would like to thank Fundação de Amparo à Pesquisa do Estado de São Paulo (Fapesp), process number 2011/18921-0 - Capes, for the financial support.

\section{REFERENCES}

1. American Dental Association Council on Scientific Affairs. Dental management of patients receiving oral bisphosphonate therapy: expert panel recommendations. J Am Dent Assoc. 2006;137:1144-50.

2. Ruggiero SL, Dodson TB, Fantasia J, Goodday R, Aghaloo T, Mehrotra B, et al. American Association of Oral and Maxillofacial Surgeons position paper on medication-related osteonecrosis of the jaw-2014 update. J Oral Maxillofac Surg. 2014;72:1938-56.

3. Compston J, Bowring C, Cooper A, Cooper C, Davies C, Francis R, et al. Diagnosis and management of osteoporosis in postmenopausal women and older men in the UK: National Osteoporosis Guideline Group (NOGG) update 2013. Maturitas. 2013;75(4):392-6.

4. Allen MR, Burr DB. The pathogenesis of bisphosphonate-related osteonecrosis of the jaw: so many hypotheses, so few data. $\mathrm{J}$ Oral Maxillofac Surg. 2009;67(5 Suppl):61-70.

5. Reid IR, Bolland MJ, Grey AB. Is bisphosphonate-associated osteonecrosis of the jaw caused by soft tissue toxicity? Bone. 2007;41(3):318-20.

6. Ruggiero SL. Bisphosphonate-related osteonecrosis of the jaws. Compend Contin Educ Dent. 2008;29(2):96-8, 100-2, 4-5.

7. Agrillo A, Filiaci F, Ramieri V, Riccardi E, Quarato D, Rinna C, et al. Bisphosphonate-related osteonecrosis of the jaw (BRONJ): 5 year experience in the treatment of 131 cases with ozone therapy. Eur Rev Med Pharmacol Sci. 2012;16(12):1741-7.

8. Brozoski MA, Lemos CA, Nalerio-Homem MG, Deboni MC. Adjuvant aqueous ozone in the treatment of bisphosphonate induced necrosis of the jaws: report of two cases and long-term follow-up. Minerva Stomatol. 2014;63(1-2):35-41.

9. Martins MA, Martins MD, Lascala CA, Curi MM, Migliorati CA, Tenis CA, et al. Association of laser phototherapy with PRP improves healing of bisphosphonate-related osteonecrosis of the jaws in cancer patients: a preliminary study. Oral Oncol. 2012;48(1):79-84.

10. Romeo U, Galanakis A, Marias C, Vecchio AD, Tenore G, Palaia G, et al. Observation of pain control in patients with bisphosphonate-induced osteonecrosis using low level laser therapy: preliminary results. Photomed Laser Surg. 2011;29(7):447-52.

11. Vescovi P, Manfredi M, Merigo E, Guidotti R, Meleti M, Pedrazzi G, et al. Early surgical laser-assisted management of bisphosphonate-related osteonecrosis of the jaws (BRONJ): a retrospective analysis of 101 treated sites with long-term follow-up. Photomed Laser Surg. 2012;30(1):5-13.

12. Basso FG, Turrioni AP, Soares DG, Bagnato VS, Hebling J, Souza Costa CA. Low-level laser therapy for osteonecrotic lesions: effects on osteoblasts treated with zoledronic acid. Support Care Cancer. 2014;22(10):2741-8. doi: 10.1007/ soo520-014-2267-3.

13. Lavos-Valereto IC, Deboni MC, Azambuja N Jr, Marques MM. Evaluation of the titanium Ti-6Al-7Nb alloy with and 
without plasma-sprayed hydroxyapatite coating on growth and viability of cultured osteoblast-like cells. J Periodontol. 2002;73(8):900-5. PubMed PMID: 12211500.

14. Togashi AY, Cirano FR, Marques MM, Pustiglioni FE, Lima LAPA. Characterization of bone cells obtained from the calvaria of neonatal rats (osteo-1) after serial subculture. J Applied Oral Sciences. 2007;15(5):442-447.

15. Mosmann T. Rapid colorimetric assay for cellular growth and survival: application to proliferation and cytotoxicity assays. J Immunol Methods. 1983;65(1-2):55-63.

16. Marx RE. Pamidronate (Aredia) and zoledronate (Zometa) induced avascular necrosis of the jaws: a growing epidemic. $\mathrm{J}$ Oral Maxillofac Surg. 2003;61(9):1115-7.

17. Marx RE, Cillo JE Jr., Ulloa JJ. Oral bisphosphonate-induced osteonecrosis: risk factors, prediction of risk using serum CTX testing, prevention, and treatment. J Oral Maxillofac Surg. 2007;65(12):2397-410.

18. Moreira MS, Velasco IT, Ferreira LS, Ariga SK, Abatepaulo F, Grinberg LT, et al. Effect of laser phototherapy on wound healing following cerebral ischemia by cryogenic injury. $\mathrm{J}$ Photochem Photobiol B. 2011;105(3):207-15. doi: 10.1016/j. jphotobiol.2011.09.005.

19. Ruggiero SL, Dodson TB, Assael LA, Landesberg R, Marx RE, Mehrotra B. American Association of Oral and Maxillofacial Surgeons position paper on bisphosphonate-related osteonecrosis of the jaws:2009 update. J Oral Maxillofac Surg. 2009;67(5 Suppl):2-12.

20. Dantas CM, Vivan CL, Ferreira LS, Freitas PM, Marques MM. In vitro effect of low intensity laser on the cytotoxicity produced by substances released by bleaching gel. Braz Oral Res. 2010;24(4):460-6.

21. Diniz IM, Matos AB, Marques MM. Laser phototherapy enhances mesenchymal stem cells survival in response to the dental adhesives. Scientific World Journal. 2015;2015:671789. doi: 10.1155/2015/671789.

22. Scheper M, Chaisuparat R, Cullen K, Meiller T. A novel soft-tissue in vitro model for bisphosphonate-associated osteonecrosis. Fibrogenesis Tissue Repair. 2010;3:6.

23. Moreira MS, Katayama E, Bombana AC, Marques MM. Cytotoxicity analysis of alendronate on cultured endothelial cells and subcutaneous tissue. a pilot study. Dent Traumatol. 2005;21(6):329-35.

24. Correia VF, Caldeira CL, Marques MM. Cytotoxicity evaluation of sodium alendronate on cultured human periodontal ligament fibroblasts. Dent Traumatol. 2006;22(6):312-7.
25. Rupel K, Ottaviani G, Gobbo M, Contardo L, Tirelli G, Vescovi $\mathrm{P}$, et al. A systematic review of therapeutical approaches in bisphosphonates-related osteonecrosis of the jaw (BRONJ). Oral Oncol. 2014;50(11)1049-57.

26. Scoletta M, Arduino PG, Reggio L, Dalmasso P, Mozzati M. Effect of low-level laser irradiation on bisphosphonateinduced osteonecrosis of the jaws: preliminary results of a prospective study. Photomed Laser Surg. 2010;28(2):179-84. 27. Azevedo LH, Paula Eduardo F, Moreira MS, Paula Eduardo C, Marques MM. Influence of different power densities of LILT on cultured human fibroblast growth: a pilot study. Lasers in medical science. 2006;21(2):86-9.

28. Eduardo FP, Mehnert DU, Monezi TA, Zezell DM, Schubert MM, Eduardo CP, et al. Cultured epithelial cells response to phototherapy with low intensity laser. Lasers in surgery and medicine. 2007;39(4):365-72.

29. Eduardo FP, Bueno DF, Freitas PM, Marques MM, PassosBueno MR, Eduardo CP, et al. Stem cell proliferation under low intensity laser irradiation: a preliminary study. Lasers in surgery and medicine. 2008;40(6):433-8.

30. Almeida-Lopes L, Rigau J, Zangaro RA, Guidugli-Neto J, Jaeger MM. Comparison of the low-level laser therapy effects on cultured human gingival fibroblasts proliferation using different irradiance and same fluence. Lasers in surgery and medicine. 2001;29(2):179-84.

31. Chen CH, Hung HS, Hsu SH. Low-energy laser irradiation increases endothelial cell proliferation, migration, and eNOS gene expression possibly via $\mathrm{PI} 3 \mathrm{~K}$ signal pathway. Lasers in surgery and medicine. 2008;40(1):46-54.

32. Damante CA, Micheli G, Miyagi SP, Feist IS, Marques MM. Effect of laser phototherapy on the release of fibroblast growth factors by human gingival fibroblasts. Lasers Med Sci. 2009;24(6):885-91. doi: 10.1007/s10103-008-0582-y.

33. Diniz IMA, Carreira ACO, Sipert CR, Uehara CM, Moreira MSN, Freire L, et al. Photobiomodulation of mesenchymal stem cells encapsulated in an injectable rhBMP4-loaded hydrogel directs hard tissue bioengineering. J Cell Physiol. 2018;233(6):4907-4918. doi: 10.1002/jcp.26309.

34. Pedroni ACF, Diniz IMA, Abe GL, Moreira MS, Sipert CR, Marques MM. Photobiomodulation therapy and vitamin C on longevity of cell sheets of human dental pulp stem cells. J Cell Physiol. 2018;233(10):7026-7035. doi: 10.1002/jcp.26626.

35. Eduardo FP, Bueno DF, Freitas PM, Marques MM, PassosBueno MR, Eduardo CP, et al. Stem cell proliferation under low intensity laser irradiation: a preliminary study. Lasers Surg Med. 2008;40(6):433-8. doi: 10.1002/lsm.20646. 